IZA DP No. 7299

The Impact of Legalized Casino Gambling on Crime

Mark W. Nichols

Mehmet Serkan Tosun

March 2013

Forschungsinstitut zur Zukunft der Arbeit Institute for the Study of Labor 


\title{
The Impact of Legalized Casino Gambling on Crime
}

\author{
Mark W. Nichols \\ University of Nevada-Reno \\ Mehmet Serkan Tosun \\ University of Nevada-Reno \\ and IZA
}

Discussion Paper No. 7299

March 2013

\author{
IZA \\ P.O. Box 7240 \\ 53072 Bonn \\ Germany \\ Phone: +49-228-3894-0 \\ Fax: +49-228-3894-180 \\ E-mail: iza@iza.org
}

Any opinions expressed here are those of the author(s) and not those of IZA. Research published in this series may include views on policy, but the institute itself takes no institutional policy positions. The IZA research network is committed to the IZA Guiding Principles of Research Integrity.

The Institute for the Study of Labor (IZA) in Bonn is a local and virtual international research center and a place of communication between science, politics and business. IZA is an independent nonprofit organization supported by Deutsche Post Foundation. The center is associated with the University of Bonn and offers a stimulating research environment through its international network, workshops and conferences, data service, project support, research visits and doctoral program. IZA engages in (i) original and internationally competitive research in all fields of labor economics, (ii) development of policy concepts, and (iii) dissemination of research results and concepts to the interested public.

IZA Discussion Papers often represent preliminary work and are circulated to encourage discussion. Citation of such a paper should account for its provisional character. A revised version may be available directly from the author. 


\section{ABSTRACT}

\section{The Impact of Legalized Casino Gambling on Crime*}

We examine the impact of legalized casino gambling, including Indian casinos, on crime. Using county-level data between 1994 and 2009, the impact that casino legalization had on crime is examined. Our results show an increase in crime associated with casinos in some circumstances, but not others. Crime impact results are quite sensitive to data, sample periods and econometric specifications. In addition to known Part 1 offenses (assault, burglary, larceny, robbery, rape, and auto theft), we also examine various arrest classifications, including driving under the influence (DUI), fraud, and prostitution. Again, casinos are associated with a statistically significant increase in some circumstances but not in others, with results depending on econometric specification. In no circumstances, however, are casinos and crime significantly negatively correlated.

JEL Classification: H71, L83

Keywords: casino gambling, crime

Corresponding author:

Mehmet Serkan Tosun

Department of Economics

University of Nevada-Reno

Mail Stop 0030

Reno, Nevada 89557

USA

E-mail: tosun@unr.edu

\footnotetext{
* We would like to thank A.J. Davis and Karl Geisler for outstanding research assistance. We are especially grateful to Jonathan Taylor for providing the opening dates for the Indian casinos.
} 
"Even as I approach the gambling hall, as soon as I hear, still two rooms away, the jingle of money poured out on the table, I almost go into convulsions.”

From The Gambler (1867) by Fyodor Dostoevsky, Chapter 17, page $188^{1}$

\section{Introduction}

Casino gambling has always been a controversial issue for national and subnational governments due to their complex socioeconomic impact. The United States Congress enacted the National Gambling Impact Study Commission Act in 1996 to study the social and economic aspects of gambling in the U.S. The Commission's final report included a number of recommendations that would significantly limit gambling activities in the U.S. ${ }^{2}$ Despite those recommendations the spread of casino gambling has been remarkable over the last two decades. In 1990 only three states, Nevada, New Jersey and South Dakota had legalized casino gambling (see Figure 1). In 2012, that number, including Indian casinos, has spread to thirty three. Figure 2 shows the distribution of states with legalized gambling on January 1, 2012. In 2012, twenty-three states had Indian casinos and seventeen had commercial casinos. ${ }^{3}$ This expansion continues, with casinos in Ohio opening in May 2012 and casinos being legalized in Massachusetts with an anticipated opening of 2014.

The expansion has been controversial, with the benefits versus costs of casino gambling being heavily debated. Jurisdictions legalizing gambling frequently reference the increase in tax revenues, jobs, and other economic development initiatives, or the loss of those to a neighboring state, as the driving force behind legalization. On the cost side,

\footnotetext{
${ }^{1}$ See Wasiolek (1972)

2 The full report of the Commission and recommendations can be found at http://govinfo.library.unt.edu/ngisc/.

3 The total number of states with casinos is fewer than the number of states with Indian casinos and commercial casinos combined since some states have both. Also, the legality of Indian casinos over time has not always been clear. Alabama, for example, has electronic gaming machines but their legal status has been challenged.
} 
one important issue is the possible causal link between casinos and crime. This particularly relates to the prevalence of compulsive gambling behavior which is often associated with higher crime rates in communities. It is well known that famous Russian writer Fyodor Dostoevsky was a compulsive gambler and it is argued that he wrote some of his most popular books (including Crime and Punishment) with tight deadlines to pay back his gambling debt. ${ }^{4}$ He also wrote his book Gambler as an autobiography in which he explains the intricacies of the gambling life of a compulsive gambler. ${ }^{5}$

In this paper, we examine the impact of legalized casino gambling, including Indian casinos, on crime. Using panel data on all U.S. counties for the period 1994 to 2009 and various regression techniques, including difference in differences estimation, we examine the impact that casino expansion had on crime (offenses and arrests).

Our results show an increase in crime associated with casino expansion in some circumstances, but not others, with the results particularly contingent upon the selection of control variables. In no circumstances, however, are casinos negatively associated with crime.

The paper is structured as follows. In the next section we review the literature on casino impacts on crime. We provide a detailed description of data and our empirical model in Section 3. Particular attention is given to the crime data and our criteria for which counties and time periods to analyze. In Section 4 we present our empirical results from a regression analysis. We summarize our results and provide a discussion with our concluding remarks in the final section.

\footnotetext{
${ }^{4}$ See Anderson (2001) and Johns on (1998).

${ }^{5}$ See Wasiolek (1972)
} 


\section{Previous Studies}

Just as the spread of casino gambling has been politically divisive, the academic literature has reached different conclusions on its impact, depending upon the sample and methodology used. Two of the most geographically extensive studies are Evans and Topoleski (2002) and Grinols and Mustard (2006). Evans and Topoleski examine the impact of Indian casinos on crime using data from 1985-1998 for all counties in the United States. Crime data are notoriously problematic in that they are self-reported and missing data is imputed using various algorithms (discussed more below). Evans and Topoleski exclude county/year observations that are largely imputed by limiting their sample to those counties that reported actual data $80 \%$ of the time during each year and those counties where $80 \%$ of the county's population is represented by the reported data. Evans and Topoleski find a significant increase in property crime four years after the opening of Indian casinos, all of which is due to an increase in larceny and auto theft. A positive and significant impact on violent crimes is also found 4 years after the opening of a casino.

Grinols and Mustard (2006) examine the impact of all casinos, not just Indian casinos, on crime using data from 1977 to 1996 for all counties in the United States. Grinols and Mustard find a significant increase in crime for all offenses except murder beginning four years after a casino opens. Unlike Evans and Topoleski, however, Grinols and Mustard do not restrict their sample to exclude those counties where significant imputations were made.

Stitt, Nichols, and Giacopassi (2003) only examine six communities that introduced casinos in the early 1990’s but examine not only Part I (murder, rape, aggravated assault, robbery, larceny, burglary, and auto theft) but also Part II offenses, 
which include fraud, embezzlement, and prostitution to name a few. In addition, crime rates per capita and per population at risk, which includes residents and visitors to the community, are examined. The six chosen communities (Alton and Peoria, IL; Sioux City, IA; Biloxi, MS; St. Joseph and St. Louis, MO) were compared with matched control jurisdictions based on fifteen socio-demographic characteristics. The results were mixed, with some crimes increasing in some communities and decreasing in others. Similarly, some communities showed more increases in crime (e.g., Biloxi and Peoria), whereas others showed more decreases (e.g., Alton). Adjusting for population at risk made little difference to the qualitative conclusions.

Reece (2010) also examines a geographically limited sample, focusing on the state of Indiana over the 1994-2004 period. Like Evans and Topoleski (2002) Reece limits his sample to limit the impact of imputed crime rates. Reece only uses counties that reported a full 12 months of data and whose population of the agencies reporting the data represents at least $60 \%$ of the county's total population. Reece also controls for the number of hotel rooms as well as casino visits using turnstile counts. Reece finds a significant increase in burglaries a few years after a casino has opened. When examining the impact of casino activity measured by visits to casinos, Reece finds a significant decrease in larceny, motor vehicle theft, aggravated assault, and robbery.

Given the variation in results and different conclusions in the current literature, it is important to examine further the link between casinos and crime taking into consideration the increased casino activity throughout the US in recent times and problems with crime data, which we discuss below in the next section. 


\section{Data and Empirical Methodology}

This study uses county level data for counties in the U.S. that legalized casino gambling. County level data on income and population as well as other demographic data including the male, Caucasian, and elderly (over 65 years of age) population are from the U.S. Census Bureau. County-level unemployment data are from the Bureau of Labor Statistics.

County level crime data, including the number of known offenses and arrests, are available for the years 1984-1992 and 1994-2009. These data are from the FBI's Uniform Crime Reports and were gathered from the National Archive of Criminal Justice Data (NACJD), part of the Inter-University Consortium for Political and Social Research at the University of Michigan.

Several caveats should be noted regarding the crime data. First, beginning in 1994, the NAJCD changed the algorithm used to impute incomplete jurisdictional reporting. Specifically, for jurisdictions reporting between 3 and 11 months of data annual totals were imputed using a weighted average [12/months reported] of existing data. For jurisdictions reporting 2 or fewer months, annual totals are based on demographically similar jurisdictions. A coverage index indicating the percentage of months actual data were reported is also included. In addition, a population coverage index, representing the percent of the county's population represented by the jurisdictions reporting, is also included. In contrast, between 1984 and 1992 only jurisdictions reporting at least 6 months of data were reported by the NACJD and no coverage index or population coverage index is available. Jurisdictions that reported fewer than 6 months of data are coded as zero, thereby making it impossible to distinguish whether a zero represents no crime or fewer than 6 months of reporting. Moreover, given the absence of 
a coverage index variable, it is impossible to distinguish whether year-to-year changes in crime reflect actual changes or result from difference due to imputation. Therefore, comparisons between the two data sets must be made with caution.

To minimize bias introduced by the different imputation algorithms the current study limits the sample to the 1994-2009 period using only those counties in time that report a complete 12 months of data, i.e., a coverage index of 100, and represent at least $60 \%$ of the county's total population, i.e., a population coverage equal to or exceeding $60 \%$.

To analyze the socioeconomic impact casinos had at the county level, the following difference-in-differences regression is estimated:

$$
\begin{aligned}
& \text { CRIME }_{j, t}=\beta_{0}+\beta_{1} \text { CASINOCOUNTY }_{j, t}+\beta_{2} \operatorname{CASINOLEGAL~}_{j, t}+ \\
& \beta_{3}\left(\text { CASINOCOUNTY } * C O_{j, t}+\Theta_{j, t} \boldsymbol{X}_{j, t}+\kappa_{j}+\tau_{t}+\varepsilon_{j, t}\right.
\end{aligned}
$$

In equation (1) $\mathrm{CRIME}_{\mathrm{j}, \mathrm{t}}$ represents various per capita offense and arrest data for county $\mathrm{j}$ at time t. CASINOCOUNTY $\mathrm{j}$ is a dummy variable equal to one for those counties that have casinos, irrespective of whether casinos were legal at time t. This variable captures the possible differences between casino and non-casino counties prior to the opening of a casino. CASINOLEGAL $\mathrm{L}_{\mathrm{t}}$ is a dummy variable equal to one when casino gambling was legalized in the state. This variable captures the changes in $\mathrm{CRIME}_{\mathrm{j}, \mathrm{t}}$ for all counties located in the state that would have occurred over time in the absence of casinos being legalized. $\mathrm{CO}_{\mathrm{j}, \mathrm{t}}$ is a dummy variable equal to one if county $\mathrm{j}$ had a casino operating within its borders for the full year before year t. (CASINOCOUNTY*CO) $)_{\mathrm{j}, \mathrm{t}}$ represents our "treatment" variable, the opening of casinos, and the coefficient $\beta_{3}$ therefore captures the change in $\mathrm{CRIME}_{\mathrm{j}, \mathrm{t}}$ occurring over time in counties that opened a casino relative to 
those that did not. ${ }^{6} \mathrm{X}_{\mathrm{j}, \mathrm{t}}$ is a set of county specific control variables and includes the percent of the total population that is male, over 65, and white; the unemployment rate; and real per capita income for county $\mathrm{j}$ at time t. $\kappa_{\mathrm{j}}$ are a set of either state or county control variables and $\tau_{\mathrm{t}}$ represent is a set of year dummy variables.

\section{Empirical Results}

Tables 1-6 present various results for the analysis that casinos had on crime.

Table 1 applies the difference in difference methodology to Part 1 crimes per capita for all states for the years 1994-2009, applying the restriction that all data is actual, rather than imputed, and represents at least $60 \%$ of the county population. Column (1) includes state and year dummies, whereas column (2) includes county and year dummies. The results suggest that the opening of casinos did not have a statistically significant impact on crime in either case. Specifically, the coefficient on casinocounty*CO, which represents the change in crime over time in casino counties when casinos actually opened is statistically insignificant.

Controlling for state-specific effects, a significant overall decline in Part 1 crimes since casino gambling was legalized is evident, but this is not the case when county dummies are included. The results using state dummies suggest that casino counties had higher crime rates than other counties, irrespective of casinos actually operating. In contrast, when including county dummies their crime rates are found to be lower. Therefore, it appears that the level of crime is very county specific, but there were no increases in those levels following the opening of casinos.

\footnotetext{
${ }^{6}$ This is the difference-in-differences methodology applied to multiple groups and time periods. Specifically, different counties opened casinos during different years. In this case CASINOCOUNTY*CO takes on values of one for the casino counties when the casinos are open, zero otherwise. This replaces the "standard” interaction variable, CASINOCOUNTY*CASINOLEGAL, see Imbens and Wooldridge (2009) for other examples of this type of interaction variable.
} 
Table 2 repeats the analysis, but only for "riverboat” states, specifically Iowa, Illino is, Missouri, Mississippi, Louisiana, and Indiana. There are several reasons for examining riverboat states separately. First, these states legalized casinos in the 1990's, which should be sufficient time for any impacts to occur. Second, casinos in these states must be located on the water or at a designated racetrack. Thus, any bias due to the selection of where casinos are located is somewhat mitigated. Table 2 again demonstrates sensitivity to the inclusion of state versus county dummies. Including state dummies, the opening of casinos are associated with an increase in Part 1 crimes of .00983 per capita, or approximately 983 additional crimes per year per 100,000. When controlling for county specific factors with county dummies, however, the impact of casinos is no longer significant, just as in the case for the United States as a whole.

Tables 3 and 4 report results for specific Part 1 crimes, with the exception of murder, where no impact is found and the numbers are frequently small. For the United States as a whole, only an increase in larceny is associated with the opening of casinos. No other crimes are significantly impacted, consistent with the results given in Table 1 . Table 4 repeats the analysis restricting the sample to riverboat states. Here increases in larceny, burglarly, and autotheft are all associated with the opening of casinos. The results also suggest a decrease in crime levels in these states since legalization and that casino counties generally had higher crime rates than non-casino counties. As with Part 1 crimes overall, no significant correlation between casinos and crime is found when controlling for county-specific effects using county dummy variables.

Table 5 reports results for selected arrest categories. Casinos frequently serve alcohol, sometimes even "complimentary" alcohol, and the opening of casinos is correlated, at the $10 \%$ significance level, with an increase in the number of dui's per 
capita. Casino counties have a higher level of dui than non-casino counties and the number of dui's has been declining over time.

Table 5 also reveals an increase in fraud related arrests associated with the opening of casinos. Finally, prostitution, which is frequently associated with casinos in the press, does not significantly change following the opening of a casino.

The results above show no clear link between casinos and crime. While there are no instances where crime significantly decreases due to the opening of casinos, increases in crime are dependent on the sample examined and specification of the difference-indifferences equation, specifically the inclusion of state versus county dummy variables.

Grinols and Mustard (2006) and Reece (2010) use an autoregressive model when examining the impact of casino gambling on crime. Specifically, they estimate a model of the following form:

$$
C R I M E_{j, t}=\beta_{0}+\sum_{i=-2}^{5} \beta_{i} \operatorname{CASINO}_{j, t+i}+\Theta_{j, t} \boldsymbol{X}_{j, t}+\kappa_{j}+\tau_{t}+\varepsilon_{j, t}
$$

where $\mathrm{CASINO}_{\mathrm{j}, \mathrm{t}+\mathrm{i}}$ equals one if county $\mathrm{j}$ has a casino open at time $\mathrm{t}+\mathrm{i}, \mathrm{i}=-2 \ldots 5$. That is, two leads and five lags of the casino opening, along with the actual opening date, are included to account for any impact casinos have on crime and to allow that impact to vary over time. Unlike the difference-in-differences methodology which estimates the longrun impact, this specification allows for the opening of casinos to have a varying short run impacts on crime during each time period. The two leads of the casino opening are designed to capture any differences between casino counties and non-casino counties and capture any changes in crime that may precede a casino opening. The lags allow for changes in crime following a casino's introduction, whereas no leads or lags, i..e., $\mathrm{i}=0$, captures the immediate impact on crime in the year a casino opens. Following Grinols and Mustard (2006) and Reece(2010), we include two leads and five lags, therefore 
examining the impact of crime over eight years: two years prior to opening, the year of opening, and five years after opening. $\mathbf{X}_{\mathrm{j}, \mathrm{t}}, \kappa_{\mathrm{j}, \mathrm{t}}$, and $\tau_{\mathrm{t}}$ are the control variables, county dummies, and year dummies, respectively, defined above.

The results of this analysis for all states and riverboat states are provided in Table 6. In both instances, the per capita crime rate for 2 years prior to the casino opening and the initial year casinos opened are not statistically significant. The insignificance of the two lead variables suggests that casino counties are not fundamentally different from non-casino counties in that prior to the casino opening there were no differences in per capita crime rates, ceteris paribus.

When examining all states, there is a significant increase in crime both one and two years after the casino opened. There is also an increase in crime 4 years after, which is significant at the $10 \%$ level. An F-test of the joint significance of the 5 lag variables is 1.86, which is significant at the $10 \%$ level. The riverboat states reveal an increase in crime occurring three and four years after the casino opened. An F test of the joint significance of the 5 lags is 2.79 , which is significant at the $5 \%$ level.

These results suggest a significant spike in crime occurring with a delay following a casino opening. After five years, however, any further increases in crime dissipate in both samples. These results also suggest that the mixed results for the difference-in-differences analysis may be due to the temporal variation in crime, as difference-in-differences analysis assumes any variation in crime will be identical for all years. 


\section{Concluding Remarks}

In this paper, we examine the impact of legalized casino gambling on crime. We examine the impact that this legalization had on counties where casinos were located. We use panel data on U.S. counties for the period 1994 to 2009 and difference in differences estimation to identify the impact before and after casino legalization.

Our results show no clear picture on the impact of casino gambling on crime. While no significant decrease in crime is ever found, significant increases are dependent upon the sample chosen and econometric specification. There is some evidence that any impact on crime may be transitory.

The results above are preliminary and several critical issues remain to be examined. One overarching issue that needs to be addressed is the spatial component of introducing casino gambling. For example, our estimates pertain to the counties in which the casinos are located. An interesting question is what happens in nearby counties, some of which are located in different states. For example, are casino impacts spilling over to or coming from nearby jurisdictions? If so that exporting or importing of crime could have important policy implications. Are the impacts different in urban as opposed to more rural counties? Do Indian casinos have the same impacts as commercial casinos?

Another issue that arises is the potential endogeneity of casino location. While casinos were restricted to being located on or near water, their placement was not random and, as was demonstrated above, the counties where they are located differed from others prior to casinos opening.

The impact of casinos on crime continues to be a debatable and sensitive issue. Further exploration into the types of crime, the sensitivity of results to sample selection, 
and the dynamics of any impacts (e.g., crime rates changing with a lag and spatial spillovers) are all important issues. 


\section{References}

Anderson, John E. “Casino Taxation in the United States,” National Tax Journal, 58 (2): 303-324.

Anderson, Susan L. On Dostoevsky. Wadsworth Philosophers Series. Belmont, CA: Wadsworth Thomson Learning.

Brown, Michael K. (1981). Working the Street: Police Discretion and the Dilemmas of Reform. New York: Russell Sage Foundation.

Crank, John P. (1990). "The Influence of Environmental and Organizational Factors on Police Style in Urban and Rural Environments." Journal of Research in Crime and Delinquency, 27 (2): 166-189.

Elliott, Donald S. and John C. Navin. 2002. "Has Riverboat Gambling Reduced State Lottery Revenue?” Public Finance Review, 30 (3): 235-247.

Evans, William, N. and Julie H. Topoleski. (2002). "The Social and Economic Impact of Native American Casinos.” National Bureau of Economic Research Working Paper, 9198, September 2002.

Garrett, Thomas, A. (2004). "Casino Gambling and Local Employment Trends." Federal Reserve Bank of St. Louis Review, 86 (1): 9-22.

Grinols, Earl L. (1994). "Bluff or Winning Hand? Riverboat Gambling and Regional Employment and Unemployment.” Illinois Business Review, 51(1): 8-11.

Grinols, Earl L., and David B. Mustard. (2006). "Casinos, Crime, and Community Costs.” Review of Economics and Statistics, 88(1), 28-45.

Imbens, Guido W. and Wooldridge, Jeffrey M. (2009). "Recent Developments in the Econometrics of Program Evaluation.” Journal of Economic Literature, 47(1) 5-86.

Johnson, Tamara. 1998. Readings on Fyodor Dostoyevsky. The Greenhaven Press

Literary Companion to World Authors. San Diego, CA: The Greenhaven Press.

Leven, Charles and Donald Phares. (1997). "Casino Gaming in Missouri: The Spending Displacement Effect and Net Economic Impact." Proceedings of the $90^{\text {th }}$ Annual Conference on Taxation, National Tax Association, Chicago, November, 431-38.

Ostrom, Elinor, Robert Parks, and Gordon P. Whitaker. (1978). "Police Agency Size: Some Evidence of its Effects.” Policy Studies Journal, 1, 34-36.

Reece, William S. (2010). “Casinos, Hotels, and Crime.” Contemporary Economic Policy, 28(2), 145-161. 
Kearney, Melissa Schettini. (2005). “The Economic Winners and Losers of Legalized Gambling,” National Tax Journal, 58 (2): 281-302.

Stitt, B. Grant, Mark W. Nichols, and David Giacopassi. (2003). "Does the Presence of Casinos Increase Crime Rates? An Examination of Casino and Control Communities.” Crime and Delinquency, 49: 253-284.

Talarico, Susette, M. and Charles R. Swanson. (1978). Styles of Policing: A Preliminary Mapping.” Policy Studies Journal, 7, 398-406.

Tosun, Mehmet S. and Mark Skidmore. "Interstate Competition and Lottery Revenues." National Tax Journal 57 No. 2 (June, 2004): 163-78.

Walker, Doug, M. and John D. Jackson. (1998). "New Goods and Economic Growth: Evidence from Legalized Gambling.” Review of Regional Studies, 28 (2): 47-69.

Walker, Doug, M. and John D. Jackson. (2007). "Do Casinos Cause Economic Growth?” American Journal of Economics and Sociology, 66 (3): 593-607.

Wasiolek, Edward. Fyodor Dostoevsky’s The Gambler with Polina Suslova's Diary. Chicago, IL: The University of Chicago Press. 

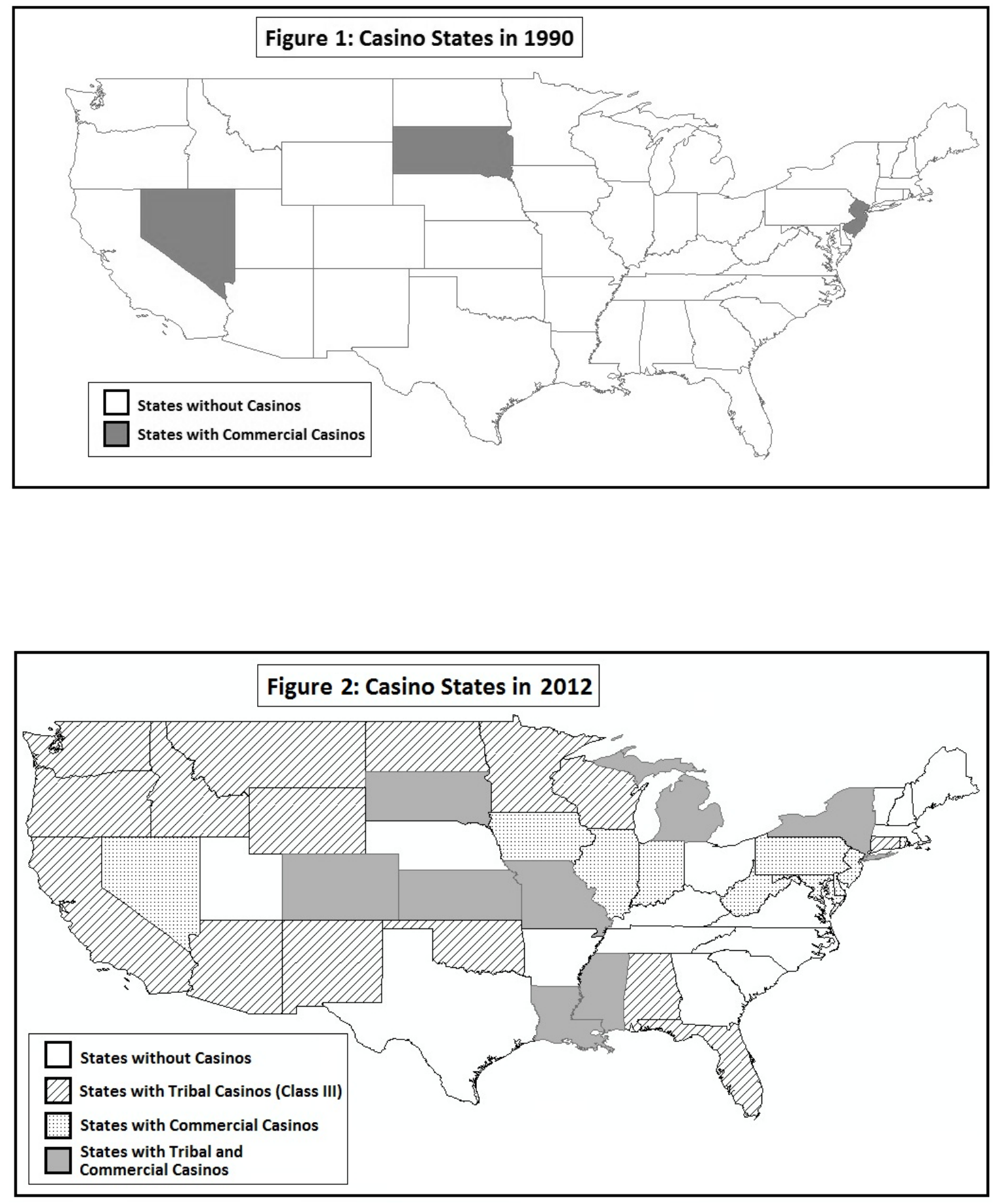
Table 1: Part 1 Crimes per Capita: 1994-2009

(All States, Coverage Index $=100$ )

\begin{tabular}{|c|c|c|}
\hline Variables & (1) & $(2)$ \\
\hline $\begin{array}{l}\text { State casino legalization } \\
\text { (1 if legalized, } 0 \text { otherwise) }\end{array}$ & $\begin{array}{c}-0.00106 * * \\
(0.000524)\end{array}$ & $\begin{array}{l}-0.000490 \\
(0.000484)\end{array}$ \\
\hline $\begin{array}{l}\text { Casino county } \\
\text { ( } 1 \text { if casino, } 0 \text { otherwise }\end{array}$ & $\begin{array}{c}0.00475 * * * \\
(0.00141)\end{array}$ & $\begin{array}{c}-0.0458 * * * \\
(0.00288)\end{array}$ \\
\hline $\begin{array}{l}\text { casinocounty*CO } \\
\text { ( } 1 \text { if casino opened, } 0 \text { otherwise) }\end{array}$ & $\begin{array}{c}0.00140 \\
(0.00157)\end{array}$ & $\begin{array}{l}-0.00120 \\
(0.000836)\end{array}$ \\
\hline $\begin{array}{l}\text { Share of male } \\
\text { population }\end{array}$ & $\begin{array}{c}-0.00163 * * * \\
(0.000143)\end{array}$ & $\begin{array}{l}0.000480 * \\
(0.000285)\end{array}$ \\
\hline $\begin{array}{l}\text { Share of population } \\
20 \text { to } 29\end{array}$ & $\begin{array}{c}0.00126 * * * \\
(0.000120)\end{array}$ & $\begin{array}{l}-0.000104 \\
(0.000255)\end{array}$ \\
\hline $\begin{array}{l}\text { Share of population } \\
65 \text { and older }\end{array}$ & $\begin{array}{c}-0.000426 * * * \\
(8.25 \mathrm{e}-05)\end{array}$ & $\begin{array}{l}-0.000140 \\
(0.000156)\end{array}$ \\
\hline $\begin{array}{l}\text { Share of white } \\
\text { population }\end{array}$ & $\begin{array}{c}-0.000247 * * * \\
(4.11 \mathrm{e}-05)\end{array}$ & $\begin{array}{c}0.000522 * * * \\
(0.000147)\end{array}$ \\
\hline $\begin{array}{l}\text { Real per capita } \\
\text { income }\end{array}$ & $\begin{array}{c}0.000413 * * * \\
(9.40 \mathrm{e}-05)\end{array}$ & $\begin{array}{c}0.000340 \\
(0.000260)\end{array}$ \\
\hline Unemployment rate & $\begin{array}{c}0.000581 * * * \\
(0.000152)\end{array}$ & $\begin{array}{l}3.93 e-05 \\
(0.000102)\end{array}$ \\
\hline Constant & $\begin{array}{l}0.102 * * * \\
(0.00987)\end{array}$ & $\begin{array}{c}-0.0355^{*} \\
(0.0183)\end{array}$ \\
\hline Year Dummies & Yes & Yes \\
\hline State Dummies & Yes & No \\
\hline County Dummies & No & Yes \\
\hline Observations & 22,024 & 22,024 \\
\hline R-squared & 0.486 & 0.854 \\
\hline $\begin{array}{l}\text { Robust standard errors in parenth } \\
* * * \mathrm{p}<0.01,{ }^{*} \mathrm{p}<0.05, * \mathrm{p}<0.1\end{array}$ & & \\
\hline
\end{tabular}


Table 2: Part 1 Crimes Per Capita: 1994-2009

(Riverboat States, Coverage Index=100)

\begin{tabular}{|c|c|c|}
\hline Variables & $(1)$ & $(2)$ \\
\hline $\begin{array}{l}\text { State casino legalization } \\
\text { ( } 1 \text { if legalized, } 0 \text { otherwise) }\end{array}$ & $\begin{array}{c}-0.00365 * * \\
(0.00185)\end{array}$ & $\begin{array}{l}0.000605 \\
(0.00139)\end{array}$ \\
\hline $\begin{array}{l}\text { Casino county } \\
\text { ( } 1 \text { if casino, } 0 \text { otherwise }\end{array}$ & $\begin{array}{l}0.00697 * \\
(0.00372)\end{array}$ & $\begin{array}{c}0.207 * * * \\
(0.0718)\end{array}$ \\
\hline $\begin{array}{l}\text { casinocounty*CO } \\
\text { ( } 1 \text { if casino opened, } 0 \text { otherwise) }\end{array}$ & $\begin{array}{l}0.00983 * * \\
(0.00442)\end{array}$ & $\begin{array}{l}-0.00109 \\
(0.00384)\end{array}$ \\
\hline $\begin{array}{l}\text { Share of male } \\
\text { population }\end{array}$ & $\begin{array}{c}-0.00261^{* * *} \\
(0.000607)\end{array}$ & $\begin{array}{c}0.00151^{*} \\
(0.000886)\end{array}$ \\
\hline $\begin{array}{l}\text { Share of population } \\
20 \text { to } 29\end{array}$ & $\begin{array}{c}0.000664 * * * \\
(0.000235)\end{array}$ & $\begin{array}{c}0.000181 \\
(0.000459)\end{array}$ \\
\hline $\begin{array}{l}\text { Share of population } \\
65 \text { and older }\end{array}$ & $\begin{array}{c}-0.000863 * * * \\
(0.000241)\end{array}$ & $\begin{array}{c}0.000151 \\
(0.000919)\end{array}$ \\
\hline $\begin{array}{l}\text { Share of white } \\
\text { population }\end{array}$ & $\begin{array}{c}-0.000493^{* *} \\
(0.000240)\end{array}$ & $\begin{array}{l}0.00217 * \\
(0.00121)\end{array}$ \\
\hline $\begin{array}{l}\text { Real per capita } \\
\text { income }\end{array}$ & $\begin{array}{c}0.000667 * * * \\
(0.000193)\end{array}$ & $\begin{array}{c}0.000318 \\
(0.000227)\end{array}$ \\
\hline Unemployment rate & $\begin{array}{c}0.000574 \\
(0.000416)\end{array}$ & $\begin{array}{l}-0.000152 \\
(0.000232)\end{array}$ \\
\hline Constant & $\begin{array}{c}0.189 * * * \\
(0.0474)\end{array}$ & $\begin{array}{c}-0.289 * * \\
(0.114)\end{array}$ \\
\hline Year Dummies & Yes & Yes \\
\hline State Dummies & Yes & No \\
\hline County Dummies & No & Yes \\
\hline Observations & 2,440 & 2,440 \\
\hline R-squared & 0.525 & 0.910 \\
\hline
\end{tabular}

Robust standard errors in parentheses

*** $\mathrm{p}<0.01,{ }^{* *} \mathrm{p}<0.05,{ }^{*} \mathrm{p}<0.1$ 
Table 3: Individual Crimes per Capita: 1994-2009

(All States, Coverage Index=100)

\begin{tabular}{|c|c|c|c|c|c|c|}
\hline VARIABLES & assault & burglary & larceny & robbery & rape & autotheft \\
\hline State casino legalization & $\begin{array}{l}-0.000243^{* * *} \\
(7.78 \mathrm{e}-05)\end{array}$ & $\begin{array}{l}-4.55 e-05 \\
(0.000147)\end{array}$ & $\begin{array}{l}-0.000315 \\
(0.000363)\end{array}$ & $\begin{array}{l}-3.65 \mathrm{e}-05 \\
(2.81 \mathrm{e}-05)\end{array}$ & $\begin{array}{l}2.24 \mathrm{e}-05^{* * *} \\
(8.02 \mathrm{e}-06)\end{array}$ & $\begin{array}{l}-8.95 e-05 \\
(6.92 e-05)\end{array}$ \\
\hline Casino county & $\begin{array}{l}0.000346^{* *} \\
(0.000170)\end{array}$ & $\begin{array}{l}0.00129 * * * \\
(0.000340)\end{array}$ & $\begin{array}{l}0.00251^{* * *} \\
(0.000868)\end{array}$ & $\begin{array}{l}8.07 e-05 \\
(7.92 e-05)\end{array}$ & $\begin{array}{l}4.79 \mathrm{e}-05^{* * *} \\
(1.44 \mathrm{e}-05)\end{array}$ & $\begin{array}{l}0.000473^{* *} \\
(0.000201)\end{array}$ \\
\hline Casinocounty*CO & $\begin{array}{l}-3.58 \mathrm{e}-05 \\
(0.000184)\end{array}$ & $\begin{array}{l}-0.000146 \\
(0.000344)\end{array}$ & $\begin{array}{l}0.00192^{*} \\
(0.00101)\end{array}$ & $\begin{array}{l}-5.25 e-05 \\
(7.85 e-05)\end{array}$ & $\begin{array}{l}2.41 \mathrm{e}-05 \\
(1.94 \mathrm{e}-05)\end{array}$ & $\begin{array}{l}0.000124 \\
(0.000239)\end{array}$ \\
\hline Constant & $\begin{array}{l}0.0108 * * * \\
(0.000962)\end{array}$ & $\begin{array}{l}0.0197 * * * \\
(0.00218)\end{array}$ & $\begin{array}{l}0.0598 * * * \\
(0.00739)\end{array}$ & $\begin{array}{l}0.00468 * * * \\
(0.000613)\end{array}$ & $\begin{array}{l}0.000865 * * * \\
(0.000120)\end{array}$ & $\begin{array}{l}0.00977 * * * \\
(0.00108)\end{array}$ \\
\hline State Dummies & Yes & Yes & Yes & Yes & Yes & Yes \\
\hline County Dummies & No & No & No & No & No & No \\
\hline Observations & 22,024 & 22,024 & 22,024 & 22,024 & 22,024 & 22,024 \\
\hline R-squared & 0.410 & 0.375 & 0.373 & 0.448 & 0.184 & 0.355 \\
\hline
\end{tabular}


Table 4: Individual Crimes per Capita: 1994-2009ª (Riverboat States, Coverage Index=100)

\begin{tabular}{|c|c|c|c|c|c|c|}
\hline VARIABLES & assault & burglary & larceny & robbery & rape & autotheft \\
\hline State casino legalization & $\begin{array}{l}-0.00109 * * * \\
(0.000308)\end{array}$ & $\begin{array}{l}-0.000863 * * \\
(0.000422)\end{array}$ & $\begin{array}{l}-0.000580 \\
(0.00122)\end{array}$ & $\begin{array}{l}-0.000201 * * \\
(8.96 \mathrm{e}-05)\end{array}$ & $\begin{array}{l}-7.90 \mathrm{e}-05^{* * *} \\
(2.19 \mathrm{e}-05)\end{array}$ & $\begin{array}{l}-0.000484^{* *} \\
(0.000228)\end{array}$ \\
\hline Casino county & $\begin{array}{l}0.000673 * \\
(0.000393)\end{array}$ & $\begin{array}{l}0.00142 * * \\
(0.000721)\end{array}$ & $\begin{array}{l}0.00372 \\
(0.00263)\end{array}$ & $\begin{array}{l}0.000342 * * \\
(0.000169)\end{array}$ & $\begin{array}{l}\text { 7.77e-05** } \\
(3.35 e-05)\end{array}$ & $\begin{array}{l}0.000718^{*} \\
(0.000426)\end{array}$ \\
\hline Casinocounty*CO & $\begin{array}{l}0.000593 \\
(0.000508)\end{array}$ & $\begin{array}{l}0.00148^{*} \\
(0.000812)\end{array}$ & $\begin{array}{l}0.00704 * * \\
(0.00294)\end{array}$ & $\begin{array}{l}0.000295 \\
(0.000208)\end{array}$ & $\begin{array}{l}5.68 \mathrm{e}-05 \\
(4.28 \mathrm{e}-05)\end{array}$ & $\begin{array}{l}0.00133^{*} \\
(0.000718)\end{array}$ \\
\hline Constant & $\begin{array}{l}0.0215 * * * \\
(0.00516)\end{array}$ & $\begin{array}{l}0.0400 * * * \\
(0.00836)\end{array}$ & $\begin{array}{l}0.102 * * * \\
(0.0295)\end{array}$ & $\begin{array}{l}0.00939 * * * \\
(0.00357)\end{array}$ & $\begin{array}{l}0.00153 * * * \\
(0.000349)\end{array}$ & $\begin{array}{l}0.0212 * * \\
(0.00871)\end{array}$ \\
\hline $\begin{array}{l}\text { State Dummies } \\
\text { County Dummies }\end{array}$ & $\begin{array}{l}\text { Yes } \\
\text { No }\end{array}$ & $\begin{array}{l}\text { Yes } \\
\text { No }\end{array}$ & $\begin{array}{l}\text { Yes } \\
\text { No }\end{array}$ & $\begin{array}{l}\text { Yes } \\
\text { No }\end{array}$ & $\begin{array}{l}\text { Yes } \\
\text { No }\end{array}$ & $\begin{array}{l}\text { Yes } \\
\text { No }\end{array}$ \\
\hline $\begin{array}{l}\text { Observations } \\
\text { R-squared }\end{array}$ & $\begin{array}{l}2,440 \\
0.435\end{array}$ & $\begin{array}{l}2,440 \\
0.383\end{array}$ & $\begin{array}{l}2,440 \\
0.453\end{array}$ & $\begin{array}{l}2,440 \\
0.486\end{array}$ & $\begin{array}{l}2,440 \\
0.323\end{array}$ & $\begin{array}{l}2,440 \\
0.396\end{array}$ \\
\hline
\end{tabular}


Table 5: Selected Arrest Categories: 1994-2009 (All States, Coverage Index=100)

\begin{tabular}{|c|c|c|c|c|c|c|}
\hline VARIABLES & duipc & embezzlepc & fraudpc & prostitutepc & drugspc & stolenproppc \\
\hline State casino legalization & $\begin{array}{c}-0.000971 * * * \\
(0.000160)\end{array}$ & $\begin{array}{l}-9.00 e-06 * \\
(5.06 e-06)\end{array}$ & $\begin{array}{c}-0.000248 * * \\
(0.000121)\end{array}$ & $\begin{array}{c}-4.47 e-07 \\
(7.67 e-06)\end{array}$ & $\begin{array}{c}-0.000423^{* *} \\
(0.000184)\end{array}$ & $\begin{array}{c}-6.74 \mathrm{e}-05 * * * \\
(1.53 \mathrm{e}-05)\end{array}$ \\
\hline Casino county & $\begin{array}{c}0.000846 * * \\
(0.000383)\end{array}$ & $\begin{array}{l}-1.42 \mathrm{e}-06 \\
(9.12 \mathrm{e}-06)\end{array}$ & $\begin{array}{l}-0.000258 \\
(0.000177)\end{array}$ & $\begin{array}{c}1.86 \mathrm{e}-06 \\
(1.93 \mathrm{e}-05)\end{array}$ & $\begin{array}{c}0.000265 \\
(0.000279)\end{array}$ & $\begin{array}{c}7.46 \mathrm{e}-05 * * \\
(3.04 \mathrm{e}-05)\end{array}$ \\
\hline Casinocounty*CO & $\begin{array}{l}0.000897^{*} \\
(0.000464)\end{array}$ & $\begin{array}{c}1.53 \mathrm{e}-05 \\
(9.89 \mathrm{e}-06)\end{array}$ & $\begin{array}{c}0.000451^{* *} \\
(0.000188)\end{array}$ & $\begin{array}{c}6.62 \mathrm{e}-06 \\
(1.96 \mathrm{e}-05)\end{array}$ & $\begin{array}{c}0.000490 \\
(0.000318)\end{array}$ & $\begin{array}{l}-3.68 \mathrm{e}-05 \\
(3.11 \mathrm{e}-05)\end{array}$ \\
\hline Constant & $\begin{array}{c}0.00261 \\
(0.00202)\end{array}$ & $\begin{array}{c}0.000170 * * * \\
(4.37 \mathrm{e}-05)\end{array}$ & $\begin{array}{c}0.00576 * * * \\
(0.00106)\end{array}$ & $\begin{array}{c}0.000486 * * * \\
(0.000128)\end{array}$ & $\begin{array}{c}0.00966 * * \\
(0.00398)\end{array}$ & $\begin{array}{c}0.00100 * * * \\
(0.000348)\end{array}$ \\
\hline $\begin{array}{l}\text { State Dummies } \\
\text { County Dummies }\end{array}$ & $\begin{array}{l}\text { Yes } \\
\text { No }\end{array}$ & $\begin{array}{l}\text { Yes } \\
\text { No }\end{array}$ & $\begin{array}{l}\text { Yes } \\
\text { No }\end{array}$ & $\begin{array}{l}\text { Yes } \\
\text { No }\end{array}$ & $\begin{array}{l}\text { Yes } \\
\text { No }\end{array}$ & $\begin{array}{l}\text { Yes } \\
\text { No }\end{array}$ \\
\hline $\begin{array}{l}\text { Observations } \\
\text { R-squared }\end{array}$ & $\begin{array}{c}22,024 \\
0.186\end{array}$ & $\begin{array}{c}22,024 \\
0.228\end{array}$ & $\begin{array}{c}22,024 \\
0.219\end{array}$ & $\begin{array}{c}22,024 \\
0.203\end{array}$ & $\begin{array}{c}22,024 \\
0.079\end{array}$ & $\begin{array}{c}22,024 \\
0.297\end{array}$ \\
\hline
\end{tabular}


Table 6: Part 1 Crimes Per Capita: 1994-2009

(Coverage Index=100)

\begin{tabular}{|c|c|c|}
\hline VARIABLES & All States & Riverboat States \\
\hline openGM & $\begin{array}{l}0.000373 \\
(0.00132)\end{array}$ & $\begin{array}{l}0.000953 \\
(0.00727)\end{array}$ \\
\hline lagopenGM & $\begin{array}{l}0.00206^{* *} \\
(0.000893)\end{array}$ & $\begin{array}{c}0.00229 \\
(0.00390)\end{array}$ \\
\hline lag2openGM & $\begin{array}{l}0.00205^{* *} \\
(0.000901)\end{array}$ & $\begin{array}{c}0.00475 \\
(0.00378)\end{array}$ \\
\hline lag3openGM & $\begin{array}{c}0.00152 \\
(0.00103)\end{array}$ & $\begin{array}{c}0.00523 * * \\
(0.00204)\end{array}$ \\
\hline lag4openGM & $\begin{array}{c}0.00140^{*} \\
(0.000761)\end{array}$ & $\begin{array}{c}0.00417^{* *} \\
(0.00190)\end{array}$ \\
\hline lag5openGM & $\begin{array}{c}0.000259 \\
(0.000799)\end{array}$ & $\begin{array}{l}0.000546 \\
(0.00205)\end{array}$ \\
\hline leadopenGM & $\begin{array}{c}0.000829 \\
(0.000844)\end{array}$ & $\begin{array}{l}0.000722 \\
(0.00223)\end{array}$ \\
\hline lead2openGM & $\begin{array}{c}0.00152 \\
(0.000947)\end{array}$ & $\begin{array}{c}0.00141 \\
(0.00255)\end{array}$ \\
\hline $\begin{array}{l}\text { Share of male } \\
\text { population }\end{array}$ & $\begin{array}{l}0.000474^{*} \\
(0.000286)\end{array}$ & $\begin{array}{c}0.00132 \\
(0.000870)\end{array}$ \\
\hline $\begin{array}{l}\text { Share of population } \\
20 \text { to } 29\end{array}$ & $\begin{array}{c}-0.000110 \\
(0.000255)\end{array}$ & $\begin{array}{c}0.000168 \\
(0.000485)\end{array}$ \\
\hline $\begin{array}{l}\text { Share of population } \\
65 \text { and older }\end{array}$ & $\begin{array}{l}-0.000118 \\
(0.000154)\end{array}$ & $\begin{array}{c}0.000182 \\
(0.000896)\end{array}$ \\
\hline $\begin{array}{l}\text { Share of white } \\
\text { population }\end{array}$ & $\begin{array}{c}0.000522 * * * \\
(0.000147)\end{array}$ & $\begin{array}{l}0.00210^{*} \\
(0.00126)\end{array}$ \\
\hline $\begin{array}{l}\text { Real per capita } \\
\text { income }\end{array}$ & $\begin{array}{c}0.000340 \\
(0.000260)\end{array}$ & $\begin{array}{c}0.000305 \\
(0.000223)\end{array}$ \\
\hline Unemployment rate & $\begin{array}{c}4.56 \mathrm{e}-05 \\
(0.000102)\end{array}$ & $\begin{array}{l}-0.000145 \\
(0.000234)\end{array}$ \\
\hline Constant & $\begin{array}{c}-0.0440 * * \\
(0.0197)\end{array}$ & $\begin{array}{c}-0.240^{* *} \\
(0.116)\end{array}$ \\
\hline $\begin{array}{l}\text { Observations } \\
\text { Number of fipscode } \\
\text { R-squared }\end{array}$ & $\begin{array}{l}22,024 \\
2,500 \\
0.486\end{array}$ & $\begin{array}{c}2,440 \\
338 \\
0.465\end{array}$ \\
\hline
\end{tabular}

